\title{
A Case Study Of Learning In A Thai Manufacturing Organization
}

Lynn L. K. Lim, (Email: lynnlim@usa.net), University of Wales Aberystwyth, United Kingdom Tritos Laosirihongthong, (Email: ltritos@engr.tu.ac.th), Thammasat University, Thailand

Christopher C. A. Chan, (Email: chris.chan@anu.edu.au), Australian National University, Australia

\begin{abstract}
This study examines the relationships between individual, team and organizational learning of 1103 workers from a Thai manufacturing organization. Individual learning was conceptualized in terms of individuals' learning strategies and motivation to learn. Team learning consisted of internal team learning and external team learning. Organizational learning was believed to be underpinned by commitment to learning, shared vision and open mindedness. These three levels of learning were inter-related. Thus, individuals who are interested in self development are more likely to contribute positively to teamwork and the benefits from the team learning could flow to the organizational level. The theoretical and practical implications are discussed.
\end{abstract}

\section{INTRODUCTION}

ome scholars and practitioners have long been fascinated by the concept of organizational learning (Baldwin, Danielson and Wiggenhorn, 1997; Easterby-Smith, 1990; Edmondson, 1999; Ellerman, 1999;

Lam, 2003). The fast pace of transformation in the business environment is believed to be responsible for compelling many organizations to learn how to improve their competitiveness (Argyris, 1991; Ellinger, Ellinger, Yang and Howton, 2002; Schein, 1996). A number of strategies to encourage organizational learning have been proposed (Goh and Richards, 1997; Mikkelsen and Gronhaug, 1999). For example, effective knowledge management appears to be progressively and widely recognized as an important antecedent of organizational learning (Collinson, 1999; Lam, 2000; Tsai, 2001). Organizational learning is, thus, seen to be a viable survival strategy for organizations operating in the $21^{\text {st }}$ century.

Researchers studying the epistemology of organizational learning have approached this topic from various perspectives. For instance, a stream of research adopts a prescriptive stance of organizational learning (Perrone, 2003; Senge, 1990, 1992, 1994; Senge, Kleiner, Roberts, Ross and Smith, 1994), focusing on what an organization should do to become a learning organization. Another stream of research seeks to understand how an organization learns (Hendry, 1996; Hult, Nichols, Giunipero and Hurley, 2000; Schulz, 2001). Besides the two streams, Easterby-Smith (1997) has identified six areas of study where the concept of organizational learning could be drawn. These include the areas of psychology and organization development, management science, sociology and organizational theory, strategy, production management, and cultural anthropology. Hence, the field of organizational learning is vast and varied.

In spite of the prolific literature on organizational learning, numerous authors with different perspectives have hinted at the roles of individual and team learning in underpinning organizational learning (Argyris, 1991; Chan, 2001; Kapp, 1999; Senge, 1992; Thompson and Zondlo, 1995). Individual learning and team learning are said to have positive effects on organizational learning, as individuals and teams bring their knowledge and experiences to other sections of the organization for organizational improvements (Bierly and Hämäläinen, 1995; Edmondson, 1996; Hayes and Allison, 1998; Kim, 1993). For example, when individuals gather to assess a problem or an issue, individuals share and exchange their knowledge, ideas and experiences (collectively termed individual learning for this study) with others in a team. Team learning is believed to have occurred when the knowledge sharing results in an expansion of team members' knowledge base and overall effectiveness in dealing with future problems (Barker and 
Neailey, 1999; Senge, 1992). When there is an opportunity for the newfound knowledge to be transferred to other parts of the organization and to be assimilated by organizational members, organizational learning is believed to have occurred (Brown and Duguid, 1998; Dodgson, 1993; Edmondson, 2002). This could be done through cross-functional team learning or inter-departmental learning. Given the importance of learning at these three levels, the limited empirical studies that systematically examine individual, team and organizational learning is unanticipated (Chan, 2003; Chan, Lim and Keasberry, 2003). Moreover, there is a noticeable dearth of reported research evidence on organizational learning in Asian organizations (Chan, 2001; Luo and Peng, 1999; Phan and Peridis, 2000). Consequently, an evaluation of learning at the individual, team and organizational levels in an Asian organization would help advance the understanding of organizational learning phenomenon.

The purpose of this study was to investigate three relationships: (1) the relationship between individual learning and team learning, (2) the relationship between individual learning and organizational learning, and (3) the relationship between team learning and organizational learning.

\section{LITERATURE REVIEW}

A review of the literature reveals two major perspectives of organizational learning i.e. the behavioral and cognitive perspectives (Yeo, 2002). The divergent views and approaches have raised much confusion, criticisms and, at the same time, provide ample research opportunities in the area of organizational learning. A brief summary of the focuses of both approaches is presented in Table 1 .

Table 1: Behavioral And Cognitive Perspectives Of Organizational Learning

\begin{tabular}{|c|c|}
\hline \multicolumn{2}{|c|}{ Behavioral Perspective Of Organizational Learning } \\
\hline Source & Descriptions Of Findings \\
\hline $\begin{array}{l}\text { Argyris (1995), Limerick, Passfield and Cunnington } \\
\text { (1994), London and Smither (1999) and Weiss (1990) }\end{array}$ & Permanent change in behavior. \\
\hline Manz and Sims (1981) & $\begin{array}{l}\text { Attention, retention, motor reproduction and motivation are } \\
\text { needed for effective learning. }\end{array}$ \\
\hline Porras and Hargis (1982) & $\begin{array}{l}\text { Behavioral change is negatively affected by stress, role ambiguity, } \\
\text { role overload and role conflict. } \\
\text { High self-regard, regard for others, self-actualization, control and } \\
\text { competence could facilitate behavioral change. }\end{array}$ \\
\hline \multicolumn{2}{|c|}{ Cognitive Perspective Of Organizational Learning } \\
\hline Source & Descriptions \& Key Findings \\
\hline Fiol and Lyles (1985) & Change does not mean that learning has occurred \\
\hline Levitt and March (1988) & $\begin{array}{l}\text { Beware of superstitious learning (interpreting certain results as } \\
\text { successful outcomes of the learning process when there is little } \\
\text { association), success learning (what works in the past will work in } \\
\text { the future) and competency traps (refusal to adopt superior } \\
\text { technology despite the availability). }\end{array}$ \\
\hline
\end{tabular}

Learning is often studied at the individual, team and organizational levels. Since individuals are the basic unit of an organization, there is a belief that an organization is capable of learning when individual members learn. This perspective uses organizational learning metaphorically in the sense that when individuals learn an organization would learn as well (Locke and Jain, 1995). Others have chosen to examine learning at the team level. As individuals bring and share their knowledge, skills and experiences to other individuals in a team (Avery, 2000; Coghlan, 2001; Delbridge, Lowe and Oliver, 2000), it is possible for individual and team learning to occur. Yet, there is a noticeable lack of empirical study of the relationships between individual, team and organizational learning. This is surprising, as there exists the individual learning scale (Ames and Archer, 1988; Sujan, Weitz and Kumar, 1994), team learning scale (Edmondson, 1996), and various organizational learning scales (Goh and Richards, 1997; Lord and Ranft, 2000; Sinkula, Baker and Noordewier, 1997). Hence, the main aim of this study is to examine the interactions of learning at the various levels. The model of learning is depicted in Figure 1 and the rationale for examining these relationships are summarized in Table 2. 


\section{Figure 1: Conceptual Model Of Learning}

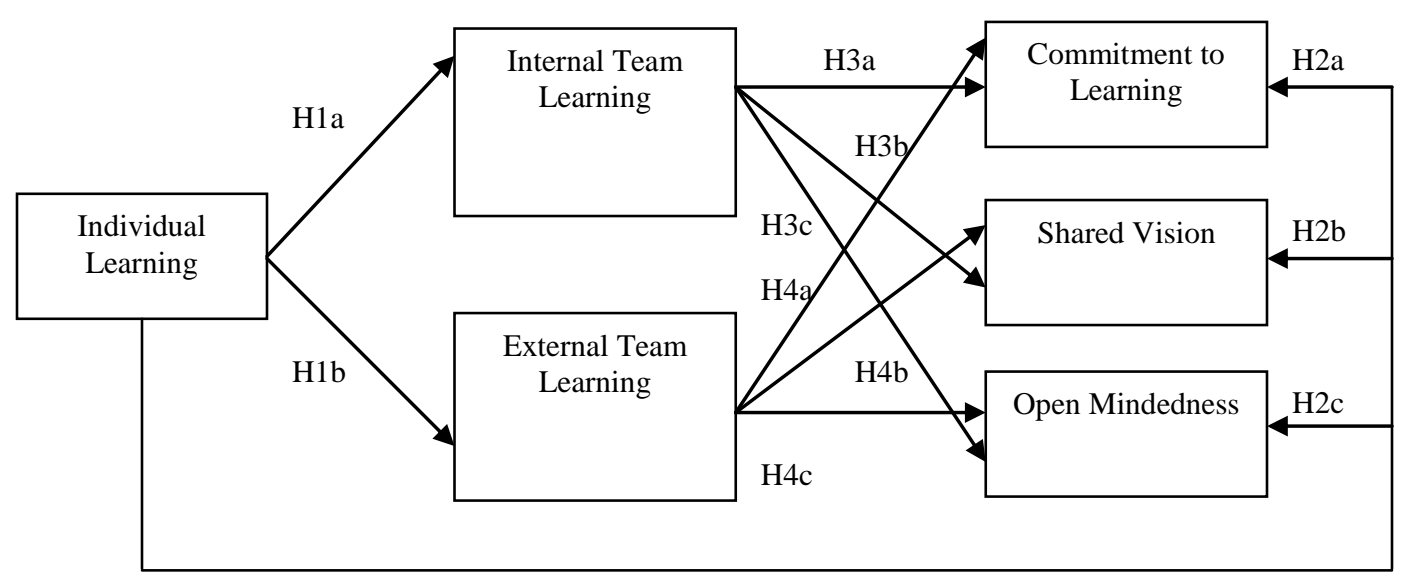

Figure 2: Conceptual Model With Results

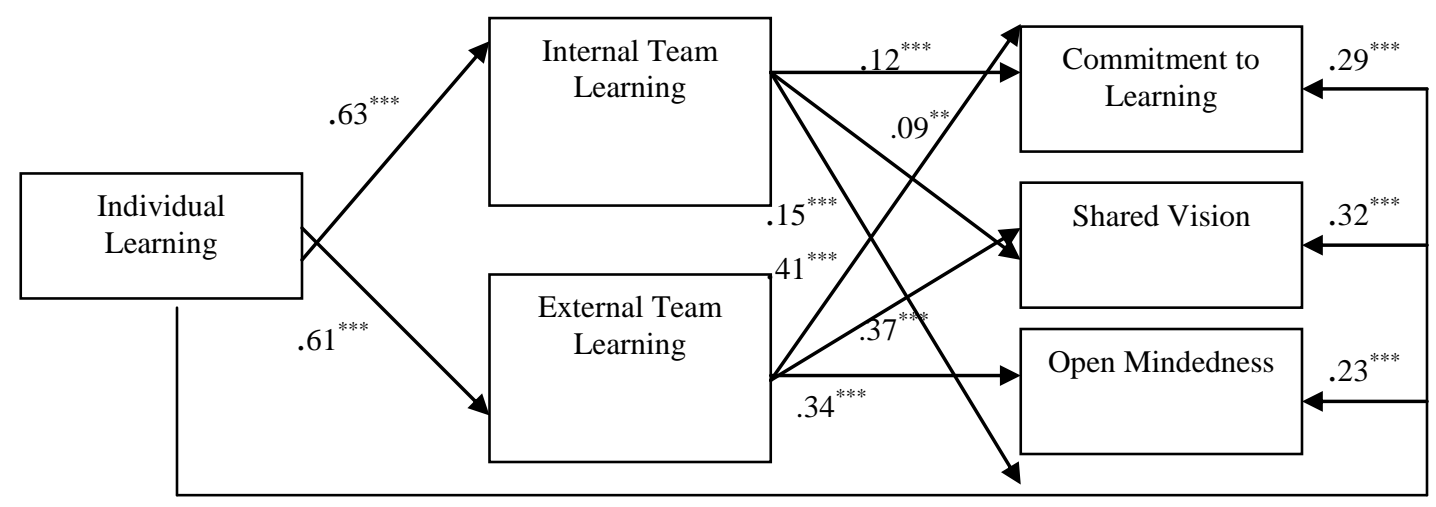

\section{Methods}

\section{Procedure And Sample}

Respondents were drawn from a Thai DVD manufacturing organization. This particular organization makes significant contributions to different industries in the Asia Pacific region, such as entertainment, multimedia, storage, training and digital media marketing (just to name a few) because of the DVD's immense storage capacity and versatility compared to floppy disks, videos, CDs and VCDs. The second author administered the questionnaires after consulting with the company's directors. One thousand one hundred and three people took part in this study, which constituted 100 percent of the workforce. This perfect response rate is attributed to the use of personal network and initiative from the organization's echelons in using this study as part of quality control. In return for participation, feedback is provided to the organization. 
Table 2: Summary Of Pertinent Literature Relating To The Relationships Between Individual, Team And Organizational Learning

\begin{tabular}{|c|c|c|c|}
\hline Study & Key Ideas & $\begin{array}{c}\text { Implications for Current } \\
\text { Study }\end{array}$ & Rationale \\
\hline $\begin{array}{l}\text { Avery (2000), Coghlan } \\
\text { (2001) and Delbridge, Lowe } \\
\text { and Oliver (2000) }\end{array}$ & $\begin{array}{l}\text { Individuals bring and share } \\
\text { knowledge with others in a } \\
\text { team. }\end{array}$ & \multirow{2}{*}{$\begin{array}{l}\text { Hypothesis 1a: Individual } \\
\text { learning is positively associated } \\
\text { with internal team learning. } \\
\text { Hypothesis } 1 \mathrm{~b} \text { : Individual } \\
\text { learning is positively associated } \\
\text { with external team learning. }\end{array}$} & \multirow{2}{*}{$\begin{array}{l}\text { Lack of empirical study of } \\
\text { the relationship between } \\
\text { individual and team } \\
\text { learning, especially in } \\
\text { developing countries. }\end{array}$} \\
\hline $\begin{array}{l}\text { Bain (1998), Bierly and } \\
\text { Hämäläinen (1995), and } \\
\text { Brown and Duguid (1998) }\end{array}$ & $\begin{array}{l}\text { Organizations are able to } \\
\text { learn only if teams in } \\
\text { organizations learn } \\
\text { collectively through the } \\
\text { experience and knowledge } \\
\text { sharing among individuals. }\end{array}$ & & \\
\hline $\begin{array}{l}\text { Hayes and Allinson (1998), } \\
\text { Lundberg (1995), Marsick } \\
\text { and Neaman (1996), Popper } \\
\text { and Lipshitz (1998), Richter } \\
\text { (1998), Senge (1992), } \\
\text { Simon (1999) and Watkins } \\
\text { (1996) }\end{array}$ & $\begin{array}{l}\text { Individual learning can } \\
\text { transpire to the } \\
\text { organizational level. }\end{array}$ & \multirow{2}{*}{$\begin{array}{l}\text { Hypothesis } 2 \mathrm{a} \text { : Individual } \\
\text { learning is positively associated } \\
\text { with commitment to learning. } \\
\text { Hypothesis } 2 \mathrm{~b} \text { : Individual } \\
\text { learning is positively associated } \\
\text { with shared vision. } \\
\text { Hypothesis } 2 \mathrm{c} \text { : Individual } \\
\text { learning is positively associated } \\
\text { with open mindedness. }\end{array}$} & \multirow{2}{*}{$\begin{array}{l}\text { There is a paucity of } \\
\text { empirical research that } \\
\text { examines the relationship } \\
\text { between individual and } \\
\text { organizational learning. } \\
\text { Richter (1998) argues that } \\
\text { such an examination is } \\
\text { needed to advance the } \\
\text { organizational learning } \\
\text { theory. }\end{array}$} \\
\hline $\begin{array}{l}\text { Dar-el, Ayas and Gilad } \\
\text { (1995), Malter and Dickson } \\
\text { (2001), Seely and Duong } \\
\text { (2001) }\end{array}$ & $\begin{array}{l}\text { Organizational learning and } \\
\text { related benefits are } \\
\text { considered outcomes of a } \\
\text { properly managed } \\
\text { individual learning process. }\end{array}$ & & \\
\hline $\begin{array}{l}\text { Gupta and Govindarajan } \\
\text { (1994) and Senge (1992) }\end{array}$ & $\begin{array}{l}\text { An organization could learn } \\
\text { when teams share insights } \\
\text { and knowledge across the } \\
\text { business. }\end{array}$ & $\begin{array}{l}\text { Hypothesis 3a: Internal team } \\
\text { learning is positively associated } \\
\text { with commitment to learning. } \\
\text { Hypothesis } 3 \mathrm{~b} \text { : Internal team } \\
\text { learning is positively associated } \\
\text { with shared vision. } \\
\text { Hypothesis } 3 \mathrm{c} \text { : External team } \\
\text { learning is positively associated } \\
\text { with open mindedness. } \\
\text { Hypothesis } 4 \mathrm{a} \text { : External team } \\
\text { learning is positively associated } \\
\text { with commitment to learning. } \\
\text { Hypothesis } 4 \mathrm{~b} \text { : External team } \\
\text { learning is positively associated } \\
\text { with shared vision. } \\
\text { Hypothesis } 4 \mathrm{c} \text { : External team } \\
\text { learning is positively associated } \\
\text { with open mindedness. }\end{array}$ & $\begin{array}{l}\text { There has been very little } \\
\text { empirical research that } \\
\text { explores the links between } \\
\text { team and organizational } \\
\text { learning (Chan } \text { et al., } \\
\text { 2003) }\end{array}$ \\
\hline
\end{tabular}

The results for the hypothesized relationships are also shown in the conceptual model, which is presented in

The demographic profiles of the respondents were as follows. A majority of the participants were female $(89.8 \%)$. In terms of managerial level, $3.8 \%$ were at senior management level, $21.2 \%$ were at the middle management level, and $75.0 \%$ were at the front line level. As for educational attainment, $84.5 \%$ had secondary schooling, $10.2 \%$ had either a college certificate or diploma, and 5.3\% held a university degree. The respondents' average organizational tenure was 5.3 years and their average experience in the industry was 5.7 years.

\section{Measures}

Individual learning was measured using a nine-item scale adapted from Sujan et al. (1994). The original individual learning instrument was developed by Ames and Archer (1988), which was used to assess students' learning strategies and motivation processes. Subsequently, Sujan et al. (1994) adapted the items to make the 
instrument relevant for assessing salespeople's individual learning behavior. Hence, for the purpose of our study, all nine items were further refined to make the instrument relevant for individuals in various occupational groups. Respondents are required to indicate how they learnt as individuals. Examples of the items used include "An important part of being a good employee/manager is continually improving your sales skills," "It is important for me to learn from each experience I have" and "I put in a great deal of effort sometimes in order to learn something new." For this and all subsequent scales, response options ranged from 1 (Strongly disagree) to 7 (Strongly agree).

Team learning was measured using the instrument developed by Edmondson (1996). This instrument consists of two parts, internal team learning (six items) and external team learning (five items). Edmondson (1996) defined internal team learning as "the extent to which team members engage in behaviors to monitor performance against goals, obtain new information, test assumptions, and create new possibilities" (p. 164) and external team learning as "an assessment by several of the team's customers and/or managers about the extent to which team engages in behaviors such as seeking new information or asking those who receive or use its work for feedback."

Organizational learning was assessed using the learning orientation scale, which was designed by Baker and Sinkula (1999). Three constructs (commitment to learning, shared vision and open mindedness) are believed to be values espoused by organizations that learn (Baker and Sinkula, 1999; Senge, 1992). Each construct consists of six items. For illustration purpose, two items from commitment to learning include "The basic values of this business unit include learning as key to improvement" and "The sense around here is that employee learning is an investment, not an expense." Next, two items from shared vision include "All employees are committed to the goals of this business unit" and "Employees view themselves as partners in charting the direction of the business unit." Finally, items from open mindedness include "Our business unit places a high value on open mindedness" and "Managers encourage employees to 'think outside the box'."

Analysis

Three statistical approaches were employed to analyze the data. First, descriptive statistics was used to report the demographic data. Second, reliability analysis was applied to test the internal consistency of the scales. Third, general linear modeling was utilized to examine the hypotheses. These three analyses were performed with the Statistical Package for the Social Sciences (SPSS Version 11).

\section{RESULTS}

The reliability estimates for the three scales used in this study were assessed using Cronbach alpha coefficient (Cronbach, 1951). This statistical method is usually used to assess the internal consistencies of an instrument's scales. According to Nunnally (1978), items in a scale are retained when the item-to-total correlation is at least 0.35 , there are at least three items in a scale, and a coefficient alpha value in the order of .70 is obtained. Yet, Guildford (1965, p.31) has argued "An alpha of 0.70 to 0.98 is considered quite reliable, while values as low as 0.35 have been found acceptable when used with other measures."

By applying Nunnally's (1978) criteria, several items had to be removed. For instance, one item pertaining to individual learning (There are not a lot of new things to learn in my job) was removed because the item-to-total correlation was less than .35. Apparently, previous studies (e.g. Chan, 2003; Chan et al., 2003) that utilized the individual learning survey had reported an improvement in reliability estimates after the negatively phrased item was removed. While two items from internal team learning had to be removed, one item was removed from external team learning. In order to improve the reliability estimates of the organizational learning scales, one item was removed from commitment to learning, another item was removed from shared vision and two items were removed from open mindedness. The retained and removed items are reported in Appendix I. General improvements in the Cronbach alphas were observed as a result of removing a few items from the scales. The final reliability estimates are reported with the correlation coefficients and descriptive statistics in Table 3. 
Table 3: Descriptive Statistics And Correlation Coefficients

\begin{tabular}{|c|c|c|c|c|c|c|c|c|}
\hline Variables & Mean & SD & 1 & 2 & 3 & 4 & 5 & 6 \\
\hline 1. Individual learning & 5.04 & 0.79 & 0.76 & & & & & \\
\hline 2. Internal team learning & 4.67 & 0.96 & 0.52 & 0.69 & & & & \\
\hline 3. External team learning & 4.71 & 1.03 & 0.47 & 0.64 & 0.73 & & & \\
\hline 4. Commitment to learning & 4.73 & 1.01 & 0.48 & 0.49 & 0.59 & 0.75 & & \\
\hline 5. Shared vision & 4.97 & 0.99 & 0.48 & 0.46 & 0.56 & 0.63 & 0.79 & \\
\hline 6. Open mindedness & 4.35 & 1.01 & 0.42 & 0.46 & 0.52 & 0.57 & 0.53 & 0.62 \\
\hline
\end{tabular}

Notes: $\mathrm{n}=1103$; Cronbach alphas are reported in italics; all correlations are significant at $\mathrm{p}<0.0001$

Table 4 presents the results of GLM testing three hypothesized relationships. Hypothesis 1 predicts a positive relationship between individual learning and team learning. Results of GLM indicate individual learning is positively related to internal and external team learning. Hypothesis 2 posits a positive relationship between individual learning and organizational learning. The results of GLM show individual learning is positively related to the organizational learning facets of commitment to learning, shared vision and open mindedness. Hypothesis 3 predicts a positive relationship between team learning and organizational learning. Internal team learning as well as external team learning are positively associated with commitment to learning, shared vision and open mindedness (the three facets of organizational learning). Hence, all three hypotheses are supported.

Table 4: Results Of General Linear Modeling

\begin{tabular}{|c|c|c|c|c|c|}
\hline \multirow[b]{2}{*}{$\begin{array}{c}\text { Independent } \\
\text { Variables }\end{array}$} & \multicolumn{2}{|c|}{ Hypotheses 1a And 1b } & \multicolumn{3}{|c|}{ Hypotheses 2a, 2b, 2c, 3a, 3b, 3c, 4a, 4b And 4c } \\
\hline & $\begin{array}{l}\text { Internal Team } \\
\text { Learning }\end{array}$ & $\begin{array}{c}\text { External } \\
\text { Team } \\
\text { Learning }\end{array}$ & $\begin{array}{l}\text { Commitment } \\
\text { To Learning }\end{array}$ & Shared Vision & $\begin{array}{c}\text { Open } \\
\text { Mindedness }\end{array}$ \\
\hline $\begin{array}{c}\text { Individual } \\
\text { learning }\end{array}$ & $\begin{array}{l}.63^{* * * *} \\
(.03)\end{array}$ & $\begin{array}{l}.61^{* * * *} \\
(.04)\end{array}$ & $\begin{array}{l}.29^{* * * *} \\
(.04)\end{array}$ & $\begin{array}{l}.32^{* * * *} \\
(.04)\end{array}$ & $\begin{array}{l}.23^{* * * *} \\
(.04)\end{array}$ \\
\hline $\begin{array}{l}\text { Internal team } \\
\text { learning }\end{array}$ & & & $\begin{array}{l}.12^{* * * *} \\
(.03)\end{array}$ & $\begin{array}{l}.09^{* *} \\
(.03)\end{array}$ & $\begin{array}{l}.15^{* * * *} \\
(.04)\end{array}$ \\
\hline $\begin{array}{l}\text { External team } \\
\text { learning }\end{array}$ & & & $\begin{array}{l}.41^{* * * *} \\
(.03)\end{array}$ & $\begin{array}{l}.37^{* * * *} \\
(.03)\end{array}$ & $\begin{array}{l}.34^{* * * *} \\
(.03)\end{array}$ \\
\hline
\end{tabular}

Notes: The values in parentheses are standard errors of the betas; ${ }^{* *} p<0.01 ;{ }^{* * *} p<0.001$

\section{DISCUSSION}

The findings in this study provide support for the widely accepted anecdotal claims that learning occurs and interacts at the individual, team and organizational levels. The primary purpose of this study was to empirically examine the relationships between these three levels of learning. Specifically, the results of this study suggest the relevance of individual learning in fostering team learning and organizational learning. This finding implies three classified types of individuals are more likely to contribute positively to the learning of other team members and the organization at large. They are those (1) who are continuously improving their work skills, (2) who are motivated to learn job-relevant skills, and (3) who are willing to invest in self-improvement. In addition, the results offer support for the hypothesized relationship between team learning and organizational learning. An inference from this finding is there is a need to improve team learning capabilities. These include learning within teams as well as cross-functional team learning to encourage learning at the organizational level. The results of this study might challenge administrators of the Thai DVD manufacturing organization to explore ways to improve learning within and across teams. Thus, the empirical evidence in this study has provided an extension to current anecdotal evidence on the linkages between individual, team and organizational learning. 
The study also extends the literature by examining the internal consistencies of three scales used in assessing individual, team and organizational learning. In particular, the internal consistencies of the individual learning instrument (Sujan et al., 1994), team learning survey (Edmondson, 1996) and learning orientation scale (Baker and Sinkula, 1999) were examined. A general observation made was the removal of negatively worded items resulted in improvements of Cronbach alpha values for the scales. Although negatively worded items are used usually in conjunction with positively worded items to identify potential response bias, Herche and Engelland (1996) suggest negatively worded items could result in a degradation of a scale's uni-dimensionality, which appears to be the case in the current study. While it is beyond the scope of this study to examine the underlying reasons for the adverse effects of negatively worded items, DeVellis (1991) predicts the potential for confusion as a result of completing a lengthy questionnaire may be the culprit. Yet, an important contribution made in the current study is an examination of the efficacy of three scales used in assessing learning capabilities at different levels in an organization. The findings reported in this study provide some assurance to future researchers who might choose these three scales to study the effects of personal learning, antecedents or outcomes of team learning, and effects of organizational learning on certain outcomes. Future researchers, who are going to utilize the individual learning instrument, team learning survey and learning orientation scale, are encouraged to phrase the items positively.

In addition to the theoretical contributions, this study has a number of practical implications. For instance, managers who are interested in developing a learning organization may wish to consider how to tap people's commitment and capacity to learn at various levels. Yet, individuals are known to have unique learning preferences (Sadler-Smith, Allinson and Hayes, 2000), which is likely to pose a challenge to trainers and human resource practitioners. According to Schmidt and Ford (2003), trainers could either ignore the individual differences while applying different techniques to stimulate individual learning, use customized learning programs, or change the thought or behavior of the individuals prior to training. There are other factors that may help to explain an individual's learning behavior. Practitioners could draw from the educational and organizational psychology literature for a rich source of information about learning. For instance, a person's previously acquired knowledge may affect the selection and interpretation of future knowledge (Pintrich, Marx and Boyle, 1993). Another factor involves a person's self-efficacy, where the consideration of oneself as a learner is believed to be important in the acquisition of skills (Maurer, Wrenn, Pierce, Tross and Collins, 2003). Furthermore, perception of the environment, and not necessarily the context, has an important bearing on the use of learning processes (Gnyawali and Stewart, 2003). In this regard, the priority is on the creation of an environment that is conducive to learning. Some practical examples of creating a learning environment include empowering individuals to encourage the learning process (Leach, Wall and Jackson, 2003), creating a climate of egalitarianism and trust so people are more approachable and view mistakes as an opportunity to learn (Goh and Richards, 1997; Edmondson, 1999), and encouraging and rewarding the sharing of critical knowledge among individuals (Chan, 2001; Huber, 1991). Overall, the current study has several important practical implications for those in charge of managing learning in the manufacturing organization, and perhaps similar businesses in the region.

\section{SUGGESTIONS FOR FUTURE RESEARCH}

Extensions to the current study are encouraged. A useful extension of this study would be to consider how individual, team and organizational learning influence relevant organizational outcomes over time. More specifically, conducting a longitudinal study that examines the dynamics between these three levels of learning over a period is, arguably, helpful to better understand the generalizability of this model. Additionally, future researchers might like to consider the effects of any intervention strategy to improve learning capabilities. Another relevant extension would be to assess the effects of learning on employees' quality of work life. Future studies could also test financial performance and market performance as outcomes of organizational learning. Furthermore, there is a fascinating opportunity to delve into the characteristics and capabilities of a learning organization. Opportunities also exist for researchers who are interested in testing the efficacy of the Learning Orientation Scale (Baker and Sinkula, 1999) as well as other scales that are developed by Goh and Richards (1997) and Lord and Ranft (2000) in other organizational environments. Evidently, there are tremendous opportunities for further empirical research work in the area of organizational learning. 
Despite shedding some light on the dynamics of learning at the individual, team and organizational levels, the findings of the study have certain limitations. Given the cross-sectional nature of the design, causality among the three variables cannot be drawn. Another limitation is its exclusive focus on a particular DVD manufacturer in Thailand. Other DVD manufacturing organizations in Thailand might have different managerial practices, ethos and structures, which could affect the learning of individuals and teams. Interpretation of the results of this study should not be extended to other DVD manufacturers from other countries. Finally, as discussed earlier, there are multiple conceptualizations of organizational learning, and the current study has adopted the scales conceived by Baker and Sinkula (1999).

\section{CONCLUSION}

Overall, the evidence from this study is supportive of the contention that individual, team and organizational learning are inter-related. In particular, when individuals work together, they might share ideas, knowledge, experiences and opinions with other members within a team or with other individuals in an organization. Similarly, the flow of knowledge from one team to another is also imperative. This logic is tested empirically in the current study and the results have important theoretical and practical implications. The knowledge obtained from this study has only begun to identify some issues whose answers might illuminate researchers and practitioners. Arguably, further rigorous examination of the inter-relationships between individual, team and organizational learning in various settings is imperative for the organizational learning theory to be developed.

\section{REFERENCES}

1. Ames, Carole and Jennifer Archer, Achievement Goals in the Classroom: Students' Learning Strategies and Motivation Processes, Journal of Educational Psychology, Vol. 18 No. 3, pp. 260-267, 1988.

2. Argyris, Chris, Teaching Smart People How to Learn, Harvard Business Review, Vol. 69, No. 3, pp. 99-109, 1991.

3. Argyris, Chris, Action Science and Organizational Learning, Journal of Managerial Psychology, Vol. 10, No. 6, pp. 20-26, 1995.

4. Argyris, Chris and David A. Schön, Organizational Learning II: Theory, Method and Practice, AddisonWesley, Reading, MA, 1996.

5. Avery, Christopher M., How Teamwork Can be developed as an Individual Skill, Journal for Quality and Participation, Vol. 23, No. 4, pp. 6-13, 2000.

6. Bain, Alastair, Social Defenses against Organizational Learning, Human Relations, Vol. 51, No. 3, pp. 413429, 1998.

7. Baker, William E. and James M. Sinkula, The Synergistic Effect of Market Orientation and Learning Orientation on Organizational Performance, Journal of the Academy of Marketing Science, Vol. 27, No. 4, pp. 411-27, 1999.

8. Baldwin, Timothy T., Camden Danielson, and William Wiggenhorn, The Evolution of Learning Strategies in Organizations: From Employee Development to Business Redefinition, Academy of Management Executive, Vol. 11, No. 4, pp. 47-58, 1997.

9. Barker, Martin and Kevin Neailey, From Individual Learning to Project Team Learning and Innovation: A Structured Approach, Journal of Workplace Learning, Vol. 11, No. 2, pp. 60-67, 1999.

10. Bechtold, Brigid L. (2000). Evolving to organizational learning, Hospital Material Management Quarterly, Vol. 21 No. 3, pp. 11-25, 2000.

11. Bierly, Paul E. and Timo Hämäläinen, Organizational Learning and Strategy, Scandinavian Journal of Management, Vol. 11, No. 3, pp. 209-224, 1995.

12. Brown, John S. and Paul Duguid, Organizing Knowledge, California Management Review, Vol. 40, No. 3, pp. 90-111, 1998.

13. Chan, Christopher C. A., Cultivating a Learning Culture in South East Asian Organizations, Management Development Journal of Singapore, Vol. 10, No. 1, pp. 25-34, 2001.

14. Chan, Christopher C. A., Individual, Team and Organizational Learning in an Australian Hospital, Learning in Health and Social Care, Vol. 2, No. 4, pp. 223-235, 2003. 
15. Chan, Christopher C. A., Lynn L. K. Lim, and Siew K. Keasberry, Examining the Relationships between Individual, Team and Organizational Learning: A Brunei Case Study, The Learning Organization, Vol. 10, No. 4, pp. 228-236, 2003.

16. Coghlan, David, Insider Action Research Projects: Implications for Practicing Managers, Management Learning, Vol. 32, No. 1, pp. 49-60, 2001.

17. Collinson, Simon, Knowledge Management Capabilities for Steel Makers: A British-Japanese Corporate Alliance for Organizational Learning, Technology Analysis \& Strategic Management, Vol. 11, No. 3, pp. 337-358, 1999.

18. Cronbach, Lee J., Coefficient Alpha and Internal Structure of Tests, Psychometrika, Vol. 16, pp. 297-334, 1951.

19. Dar-el, Ezey M., Karen Ayas, and Issachar Gilad, A Dual-Phase Model for the Individual Learning Process in Industrial Tasks, IIE Transactions, Vol. 27, pp. 265-271, 1995.

20. Darr, Eric, Linda Argote, and Dennis Epple, The Acquisition, Transfer and Depreciation of Knowledge in Service Organizations: Productivity in Franchises, Management Science, Vol. 41, No. 11, pp. 1750-1762, 1995.

21. Delbridge, Rick, James Lowe, and Nick Oliver, Shopfloor Responsibilities Under Lean Teamworking, Human Relations, Vol. 53, No. 11, pp. 1459-1479, 2000.

22. DeVellis, Robert F., Scale Development: Theory and Applications, Sage, London, 1991.

23. Dodgson, Mark, Organizational Learning: A Review of Some Literature, Organization Studies, Vol. 14, No. 3, pp. 375-394, 1993.

24. Easterby-Smith, Mark, Creating a Learning Organization, Personnel Review, Vol. 19, No. 5, pp. 24-28, 1990.

25. Easterby-Smith, Mark, Disciplines of Organizational Learning: Contributions and Critiques, Human Relations, Vol. 50, No. 9, pp. 1085-1113, 1997.

26. Edmondson, Amy C., Group and Organizational Influences on Team Learning. Unpublished Doctoral Dissertation, Harvard University, Boston, MA, 1996.

27. Edmondson, Amy, Psychological Safety and Learning Behavior in Work Teams, Administrative Science Quarterly, Vol. 44, pp. 350-383, 1999.

28. Edmondson, Amy C., The Local and Variegated Nature of Learning in Organizations: A Group-Level Perspective, Organization Science, Vol. 13, No. 2, pp. 128-146, 2002.

29. Ellerman, David P., Global Institutions: Transforming International Development Agencies into Learning Organizations, Academy of Management Executive, Vol. 13, No. 1, pp. 25-35, 1999.

30. Ellinger, Andrea D., Alexander E. Ellinger, Baiyin Yang, and Shelly W. Howton, The Relationship between the Learning Organization Concept and Firms' Financial Performance: An Empirical Assessment, Human Resource Development Quarterly, Vol. 13, No. 1, pp. 5-21, 2002.

31. Fiol, C. Marlene and Marjorie A. Lyles, Organizational Learning, Academy of Management Review, Vol. 10, No. 4, pp. 803-813, 1985.

32. Gnyawali, Devi R. and Alice C. Stewart, A Contingency Perspective on Organizational Learning: Integrating Environmental Context, Organizational Learning Processes, and Types of Learning, Management Learning, Vol. 34, No. 1, pp. 63-89, 2003.

33. Goh, Swee and Gregory Richards, Benchmarking the Learning Capability of Organizations, European Management Journal, Vol. 15, No. 5, pp. 575-583, 1997.

34. Gore, Chris and Emma Gore, Knowledge Management: The Way Forward, Total Quality Management, Vol. 10, No. 5, pp. 554-560, 1999.

35. Guildford, John P., Fundamental Statistics in Psychology and Education, $4^{\text {th }}$ edn., McGraw-Hill, New York, 1965.

36. Gupta, Anil K. and Vijay Govindarajan, Organizing for Knowledge Flows within MNCs, International Business Review, Vol. 3, pp. 443-457, 1994.

37. Hayes, John and Christopher W. Allinson, Cognitive Style and the Theory and Practice of Individual and Collective Learning in Organizations, Human Relations, Vol. 51, No. 7, pp. 847-871, 1998.

38. Hendry, Chris, Understanding and Creating Whole Organizational Change Through Learning Theory, Human Relations, Vol. 49, No. 5, pp. 621-641, 1996.

39. Herche, Joel and Brian Engelland, Reversed-Polarity Items and Scale Unidimensionality, Academy of Marketing Science, Vol. 24 No. 4, pp. 366-374, 1996. 
40. Huber, George P., Organizational Learning: The Contributing Processes and the Literatures, Organization Science, Vol. 2, pp. 88-115, 1991.

41. Hult, G. Tomas M., Ernest L. Nichols, Jr., Larry C. Giunipero, and Robert F. Hurley, Global Organizational Learning in the Supply Chain: A Low Versus High Learning Study, Journal of International Marketing, Vol. 8, No. 3, pp. 61-83, 2000.

42. Kapp, Karl P. Transforming Your Manufacturing Organization into a Learning Organization, Hospital Material Management Quarterly, Vol. 20, No. 4, pp. 46-54, 1999.

43. Kim, Daniel H., The Link between Individual and Organizational Learning, Sloan Management Review, Vol. 35, No. 1, pp. 37-50, 1993.

44. Lam, Alice, Tacit Knowledge, Organizational Learning and Societal Institutions: An Integrated Framework, Organization Studies, Vol. 21, No. 3, pp. 487-513, 2000.

45. Lam, Alice, Organizational Learning in Multinationals: R\&D networks of Japanese and US MNEs in the UK, Journal of Management Studies, Vol. 40, No. 3, pp. 673-703, 2003.

46. Leach, Desmond J., Toby D. Wall, and Paul R. Jackson, The Effect of Empowerment on Job Knowledge: An Empirical Test Involving Operators of Complex Technology, Journal of Occupational and Organizational Psychology, Vol. 76, No. 1, pp. 27-52, 2003.

47. Levitt, Barbara and James March, Organizational Learning, Annual Review of Sociology, Vol. 14, pp. 319340, 1988.

48. Limerick, David, Ron Passfield, and Bert Cunnington, Transforming Change: Towards an Action Learning Organization, The Learning Organization, Vol. 1, No. 2, pp. 29-40, 1994.

49. Locke, Edwin A. and Vinod K. Jain, Organizational Learning and Continuous Improvement, International Journal of Organizational Analysis, Vol. 3, No. 1, pp. 45-68, 1995.

50. London, Manuel and James W. Smither, Empowered Self-Development and Continuous Learning, Human Resource Management, Vol. 38, No. 1, pp. 3-15, 1999.

51. Lord, Michael D. and Annette L. Ranft, Organizational Learning about New International Markets: Exploring the Internal Transfer of Local Market Knowledge, Journal of International Business Studies, Vol. 31, No. 4, pp. 573-589, 2000.

52. Lundberg, Craig C., Learning in and by Organizations: Three Conceptual Issues, International Journal of Organizational Analysis, Vol. 3, No. 1, pp. 10-23, 1995.

53. Luo, Yadong and Mike W. Peng, Learning to Compete in a Transition Economy: Experience, Environment, and Performance, Journal of International Business Studies, Vol. 30, No. 2, pp. 269-295, 1999.

54. Malter, Alan J. and Peter R. Dickson, The Effect of Individual Learning on Competitive Decision Making and Firm Performance, International Journal of Research in Marketing, Vol. 18, No. 1, pp. 99-117, 2001.

55. Manz, Charles C. and Henry P. Sims, Jr., Vicarious Learning: The Influence of Modeling on Organizational Behavior, Academy of Management Review, Vol. 6, No. 1, pp. 105-113, 1981.

56. Marsick, Victoria J. and Peter G. Neaman, Individuals Who Create Organization that Learn, New Directions for Adult and Continuing Education, Vol. 72, pp. 97-104, 1996.

57. Maurer, Todd J., Kimberly A. Wrenn, Heather R. Pierce, Stuart A. Tross, and William C. Collins, Beliefs about 'Improvability' of Career-Relevant Skills: Relevance to Job/Task Analysis, Competency Modeling, and Learning Orientation, Journal of Organizational Behavior, Vol. 24, No. 1, pp. 107-131, 2003.

58. Mikkelsen, Aslaug and Kjell Gronhaug, Measuring Organizational Learning Climate: A Cross-National Replication and Instrument Validation Study Among Public Sector Employees, Review of Public Personn

59. Nonaka, Ikujiro and Hirotaka Takeuchi, The Knowledge-Creating Company: How Japanese Companies Create the Dynamics of Innovation, Oxford University Press, New York, 1995.

60. Nunnally, Jum, Psychometric Theory, $2^{\text {nd }}$ edn., McGraw-Hill, New York, 1978.

61. Perrone, Jim, Creating a Mentoring Culture, Healthcare Executive, Vol. 18, No. 3, pp. 84-85, 2003.

62. Phan, Philip H. and Theodore Peridis, Knowledge Creation in Strategic Alliances: Another Look at Organizational Learning, Asia Pacific Journal of Management, Vol. 17, No. 2, pp. 201-222, 2000.

63. Pintrich, Paul R., Ronald W. Marx, and Robert A. Boyle, Beyond Cold Conceptual Change: The Role of Motivational Beliefs and Classroom Contextual Factors in the Process of Conceptual Change, Review of Educational Research, Vol. 63, No. 2, pp. 167-199, 1993. 
64. Popper, Micha and Raanan Lipshitz, Organizational Learning Mechanisms: A Structural and Cultural Approach to Organizational Learning, Journal of Applied Behavioral Science, Vol. 34, No. 2, pp. 161-179, 1998.

65. Porras, Jerry I. and Kenneth Hargis, Precursors of Individual Change: Responses to a Social Learning Theory Based on Organizational Intervention, Human Relations, Vol. 35, No. 11, pp. 973-990, 1982.

66. Richter, Ingrid, Individual and Organizational Learning at the Executive Level, Management Learning, Vol. 29, No. 3, pp. 299-316, 1998.

67. Sadler-Smith, Eugene, Christopher W. Allinson, and John Hayes, Learning Preferences and Cognitive Style: Some Implications for Continuing Professional Development, Management Learning, Vol. 31, No. 2, pp. 239-256, 2000.

68. Schein, Edgar H., Three Cultures of Management: The Key to Organizational Learning, Sloan Management Review, Vol. 38, No. 1, pp. 9-20, 1996.

69. Schmidt, Aaron M. and J. Kevin Ford, Learning Within a Learner Control Training Environment: The Interactive Effects of Goal Orientation and Metacognitive Instruction on Learning Outcomes, Personnel Psychology, Vol. 56, No. 2, pp. 405-429, 2003.

70. Schulz, Martin, The Uncertain Relevance of Newness: Organizational Learning and Knowledge Flows, Academy of Management Journal, Vol. 44, No. 4, pp. 661-681, 2001.

71. Seely, Mark A. and Quang P. Duong, The Dynamic Baseline Model for Project Management, Project Management Journal, Vol. 32, No. 2, pp. 25-36, 2001.

72. Senge, Peter M., The Leader's New Work: Building Learning Organizations, Sloan Management Review, Vol. 32, No. 1, pp. 7-23, 1990.

73. $\quad$ Senge, Peter M., The Fifth Discipline: The Art \& Practice of the Learning Organization, Random House Australia, Milson Point, 1992.

74. Senge, Peter M., Learning to Alter Mental Models, Executive Excellence, Vol. 11, No. 3, pp. 16-17, 1994.

75. Senge, Peter M., Art Kleiner, Charlotte Roberts, Rick Ross, and Bryan Smith, The Fifth Discipline Fieldbook: Strategies and Tools for Building a Learning Organization, Doubleday Currency, New York, 1994.

76. Simon, Neil J., The Learning Organization, Competitive Intelligence Magazine, Vol. 2, No. 2, pp. 40-42, 1999.

77. Sinkula, James M., William E. Baker, and Thomas T. Noordewier, A framework for market-based organizational learning: Linking values, knowledge, and behavior, Journal of the Academy of Marketing Science, Vol. 25, No. 4, pp. 305-318, 1997.

78. Sujan, Harish, Barton A. Weitz, and Nimalya Kumar, Learning, Orientation, Working Smart, and Effective Selling, Journal of Marketing, Vol. 58, No. 3, pp. 39-52, 1994.

79. Thompson, Carolyn J. C. and John A. Zondlo, Building a Case for Team Learning, Healthcare Forum Journal, Vol. 38, No. 5, pp. 36-43, 1995.

80. Tsai, Wenpei, Knowledge Transfer in Intraorganizational Networks: Effects of Network Position and Absorptive Capacity on Business Unit Innovation and Performance, Academy of Management Journal, Vol. 44, No. 5, pp. 996-1004, 2001.

81. Watkins, Karen E., Of Course Organizations Learn!, New Directions for Adult and Continuing Education, Vol. 72, pp. 89-96, 1996.

82. Weiss, Howard M., Learning Theory and Industrial and Organizational Psychology, in Dunnette, M.D. and Hough, L.M. (Eds) Handbook of Industrial \& Organizational Psychology, Volume 1, $2^{\text {nd }}$ edn., Palo Alto, Consulting Psychologists Press, 172-173, 1990.

83. Yeo, Roland, Learning within Organizations: Linking the Theoretical and Empirical Perspectives, Journal of Workplace Learning, Vol. 14, No. 3, pp. 109-122, 2002. 


\section{APPENDIX I}

\begin{tabular}{|c|c|c|}
\hline \multicolumn{3}{|c|}{ INDIVIDUAL LEARNING } \\
\hline 1 & There are not a lot of new things to learn in my job. & $\mathrm{X}$ \\
\hline 2 & An important part of becoming a good employee/employer is to continually improve work skills. & $\checkmark$ \\
\hline 3 & Making a tough decision is very satisfying. & $\checkmark$ \\
\hline 4 & It is important for me to learn from each of my job experiences. & $\checkmark$ \\
\hline 5 & I spend a great deal of time learning new work approaches. & $\checkmark$ \\
\hline 6 & I am always learning something new in my work. & $\checkmark$ \\
\hline 7 & Making mistakes is just part of the learning process. & $\checkmark$ \\
\hline 8 & Learning how to be a better employee/manager is of fundamental importance to me. & $\checkmark$ \\
\hline 9 & Sometimes I put a great deal of effort into learning something new. & $\checkmark$ \\
\hline \multicolumn{3}{|c|}{ TEAM LEARNING } \\
\hline \multicolumn{3}{|c|}{ Intra-team learning } \\
\hline 10 & In our team, people discuss ways to prevent and learn from mistakes. & $\checkmark$ \\
\hline 11 & We regularly take time to figure out ways to improve our work processes. & $\checkmark$ \\
\hline 12 & $\begin{array}{l}\text { Problems and errors in our team are never communicated to the appropriate people so that corrective action can be } \\
\text { taken. }\end{array}$ & $\mathrm{X}$ \\
\hline 13 & My team handles differences of opinions privately or off-line, rather than publicly. & $\mathrm{X}$ \\
\hline 14 & In my team, someone always makes sure that we stop to reflect on our work process. & $\checkmark$ \\
\hline 15 & People in my team often speak up to test assumptions about issues under discussion. & $\checkmark$ \\
\hline \multicolumn{3}{|c|}{ Inter-team learning } \\
\hline 16 & My team frequently coordinates with other teams to meet organizational objectives. & $\checkmark$ \\
\hline 17 & My team keeps others in the organization informed about what we plan and accomplish. & $\checkmark$ \\
\hline 18 & $\begin{array}{l}\text { Team members go out and get all the relevant work information they possible can from others - such as customers, } \\
\text { or other parts of the organization. }\end{array}$ & $\checkmark$ \\
\hline 19 & We invite people from outside the team to present information or have discussions with us. & $\checkmark$ \\
\hline 20 & We don't have time to communicate information about our team's work to others who are not in the team. & $\mathrm{X}$ \\
\hline \multicolumn{3}{|c|}{ ORGANIZATIONAL LEARNING } \\
\hline \multicolumn{3}{|c|}{ Commitment to learning } \\
\hline 21 & Managers basically agree that our business unit's ability to learn is the key to our competitive advantage. & $\checkmark$ \\
\hline 22 & The basic values of this business unit include learning as key to improvement. & $\checkmark$ \\
\hline 23 & The sense around here is that employee learning is an investment, not an expense. & $\checkmark$ \\
\hline 24 & Learning in my organization is seen as a key commodity necessary to guarantee organizational survival. & $\checkmark$ \\
\hline 25 & Our culture is one that does not make employee learning a top priority. & $\mathrm{X}$ \\
\hline 26 & The collective wisdom in this enterprise is that once we quit learning, we endanger our future. & $\checkmark$ \\
\hline \multicolumn{3}{|c|}{ Shared vision } \\
\hline 27 & There is a well-expressed concept of who we are and where we are going as a business unit. & $\checkmark$ \\
\hline 28 & There is a total agreement on our business unit vision across all levels, functions, and division. & $\checkmark$ \\
\hline 29 & All employees are committed to the goals of this business unit. & $\checkmark$ \\
\hline 30 & Employees view themselves as partners in charting the direction of the business unit. & $\checkmark$ \\
\hline 31 & Top leadership believes in sharing its vision for the business unit with the lower levels. & $\checkmark$ \\
\hline 32 & We do not have a well-defined vision for the entire business unit. & $\mathrm{X}$ \\
\hline \multicolumn{3}{|c|}{ Open mindedness } \\
\hline 33 & We are not afraid to reflect critically on the shared assumptions we have about the way we do business. & $\checkmark$ \\
\hline 34 & Managers in this business unit do not want their "view of the world" to be questioned. & $\mathrm{X}$ \\
\hline 35 & Our business unit places a high value on open mindedness. & $\checkmark$ \\
\hline 36 & Managers encourage employees to "think outside the box." & $\checkmark$ \\
\hline 37 & An emphasis on constant innovation is not a part of our corporate culture. & $\mathrm{X}$ \\
\hline 38 & Original ideas are highly valued in this organization. & $\checkmark$ \\
\hline
\end{tabular}

